\title{
Intra- and inter-regional diversification, subsidiary value chain activities and expatriate utilization
}

Article

Accepted Version

Creative Commons: Attribution-Noncommercial-No Derivative Works 4.0

Lee, J. M. (2019) Intra- and inter-regional diversification, subsidiary value chain activities and expatriate utilization. Journal of International Management, 25 (3). 100668. ISSN 1075-4253 doi: https://doi.org/10.1016/j.intman.2019.03.001 Available at https://centaur.reading.ac.uk/83254/

It is advisable to refer to the publisher's version if you intend to cite from the work. See Guidance on citing.

To link to this article DOI: http://dx.doi.org/10.1016/j.intman.2019.03.001

Publisher: Elsevier

All outputs in CentAUR are protected by Intellectual Property Rights law, including copyright law. Copyright and IPR is retained by the creators or other copyright holders. Terms and conditions for use of this material are defined in the End User Agreement.

www.reading.ac.uk/centaur

\section{CentAUR}


Central Archive at the University of Reading

Reading's research outputs online 


\title{
Intra- and Inter-Regional Diversification, Subsidiary Value Chain Activities and Expatriate Utilization
}

\author{
Jongmin Lee \\ Henley Business School, University of Reading
}

\begin{abstract}
Although it is well established in the current staffing literature that why and how multinational enterprises (MNEs) allocate more or fewer expatriates in some subsidiaries than others, little is known about why and how some MNEs utilize more or fewer expatriates than other MNEs. This paper builds on regionalization theory to argue that intra- and inter-regional diversification has to do with the overall use of expatriates in MNEs. An empirical investigation of Korean MNEs demonstrates that the degree of intra- and inter-regional diversification has significant impacts on the level of expatriate utilization by MNEs. The results also reveal an interesting moderating influence of subsidiary value chain activities. MNEs tend to vigorously adjust their use of expatriates in downstream subsidiaries depending on the degree of intra- and interregional diversification. However, they do not adjust their use of expatriates in manufacturing subsidiaries upon the degree of international diversification. Overall, this study extends our understanding of how MNEs manage a geographically dispersed organization in a semiglobalized world.
\end{abstract}

Keywords: multinational enterprises; intra- and inter-regional diversification; expatriate utilization; regionalization theory; subsidiary value chain activities. 


\section{Introduction}

Expatriates are generally defined as 'employees of the multinational enterprise (MNE) headquarters that are temporarily deployed abroad to accomplish an organization-related goals' (Aycan \& Kanungo, 1997). Expatriation provides MNEs with a key mechanism to exercise management control and coordinate business activities across locations (Harzing, 2001a; Tan \& Mahoney, 2006). However, excessive use of expatriates incurs high costs and impedes MNEs to benefit from local diversity (Tarique, Schuler, \& Gong, 2006). Therefore, it has been a central management decision for MNE headquarters to determine the appropriate levels of expatriate staffing, which can impact significantly on an MNE's ability to achieve learning, innovation and corporate integration (Bonache, Brewster, \& Suutari, 2001; Goerzen \& Beamish, 2007; Schuler, Dowling, \& De Cieri, 1993).

A body of literature has developed on the determinants and consequences of expatriate staffing at the subsidiary level (Gaur, Delios, \& Singh, 2007; Gong, 2003; Harzing, 2001b; Hyun, Oh, \& Paik, 2015; Peng \& Beamish, 2014; Shin, Hasse, \& Schotter, 2016). However, while these studies have shed considerable light on the expatriate staffing decisions for individual subsidiaries, there has been very little attempt to explore expatriate staffing levels at the aggregate MNE level. Although much is known about why MNEs utilize more or fewer expatriates in some subsidiaries than others, we know little about why some MNEs utilize more or fewer expatriates for international management than other MNEs. This constitutes an important management inquiry because expatriate staffing is, in essence, a managerial resource allocation decision for headquarters that primarily concerns the MNE's managerial orientation (Perlmutter, 1969) and that reflects the organizational contingencies presented by the entire portfolio of subsidiaries rather than individual subsidiaries (Nohria \& Ghoshal, 1997). It is also a critical issue in strategic human resource management that is concerned with the macroorganizational approach intended to ensure that human resource management and practices are 
fully integrated into strategic planning and cohere across firm hierarchies (Collings, Scullion, \& Dowling, 2009; Guest, 1989; Wright \& McMahan, 1992).

This paper aims to fill in this research gap by exploring whether and how the level of expatriate utilization varies across different MNEs. I build on regionalization theory and expatriation literature to develop hypotheses about the relationship between the degree of internationalization and the MNE's use of expatriates. The degree of internationalization is associated with the level of managerial complexity facing MNEs, which in turn affects the desired level of control and coordination over international activities (Verbeke, Li, \& Goerzen, 2009). While much of the literature has examined firm internationalization at the country level, there has been increasing recognition of the need to consider the role of the region in MNE operations to supplement conventional country-level analyses (Rugman \& Oh, 2013). By taking account of the region as a grouping of countries that are relatively similar to each other and dissimilar to countries in other regions, regionalization theory argues that inter-regional diversification incurs higher coordination challenges and costs than intra-regional diversification to deal with greater bounded rationality and bounded reliability constraints (Rugman \& Verbeke, 2007; Verbeke \& Asmussen, 2016). Drawing on this theory, this paper predicts that the degree of intra- and inter-regional diversification are associated with the MNE's use of expatriates for controlling and coordinating international activities. This constitutes an important and relevant question for international management because, in the face of increasing internationalization, the role of expatriates in managing overseas activities becomes more crucial while determining the appropriate level of expatriate utilization becomes more sophisticated (Collings, Scullion, \& Morley, 2007; Harzing, Pudelko, \& Reiche, 2015).

In this paper, I also consider the role of subsidiary value chain activities on expatriate utilization. Although their role has rarely been taken into account in the MNE staffing literature, subsidiary value chain activities, both theoretically and empirically, may significantly affect 
the MNE's expatriate staffing decisions (Beamish \& Inkpen, 1998). This study hypothesizes that subsidiary value chain activities moderate the relationship between the degree of internationalization and the level of expatriate utilization. Specifically, it examines whether the relationship varies between manufacturing subsidiaries (i.e., factories) and downstream subsidiaries (i.e., sales/service subsidiaries).

I test my hypotheses using South Korean (hereafter Korean) MNEs. The empirical investigation reveals that inter-regional diversification is positively associated with the MNE's overall use of expatriates while intra-regional diversification is not significantly related with the level of expatriate utilization by MNEs. However, the relationship between the MNE's international diversification and expatriate utilization is strongly contingent on subsidiary value chain activities. I find that MNEs maintain their use of expatriates in manufacturing subsidiaries no matter to what extent their manufacturing subsidiaries are intra-regionally or inter-regionally diversified. On the contrary, MNEs actively adjust their use of expatriates in downstream subsidiaries depending on the degrees of both intra- and inter-regional diversification as predicted by regionalization theory.

Overall, this study contributes to a more nuanced understanding of how MNEs manage a geographically dispersed organization in a semi-globalized world by exploring how the degrees of internationalization are related to the MNE's use of expatriates. The findings of this study demonstrate the role of geographic regions in management decisions such as expatriate utilization, generally confirming the regionalization argument (Rugman \& Oh, 2013; Verbeke \& Asmussen, 2016). However, this study also reveals that the impact of the region in MNE management may vary across the global activities of the MNE (Mudambi \& Puck, 2016). This study also extends the expatriate staffing literature by exploring the level of expatriate utilization at the aggregate MNE level and by demonstrating the role of subsidiary value chain activities. This approach and findings have important research implications. 


\section{Theoretical background}

\subsection{The role of the region in MNE strategies and operations}

The theoretical background underlying the internationalization literature is the discussion of distances. The central idea is that the risks and costs of geographical diversification increase as the distance from home country increases. In more elaborate extensions, it is the 'compounded distance' that matters (Rugman, Verbeke, \& Nguyen, 2011a), which includes not only physical, cultural and psychic distances but also a range of institutional (i.e. economic, political, financial, demographic) distances (Berry, Guillen, \& Zhou, 2010; Ghemawat, 2001) as well as the differences in language, history and ethnicity (Håkanson \& Ambos, 2010). Much of the literature has focused on a variety of dyadic distances between home and host locations as a barrier of international business, using 'country' as a relevant parameter (Rugman \& Oh, 2013). However, a country-based approach has been increasingly challenged over the last decade by the empirical reality of the 'semi-globalization' (Ghemawat, 2003) and 'regionalization' phenomenon (Rugman, 2000).

The regionalization argument arises due to substantial 'discontinuities' of distance at the regional boundary, in which the compounded distance between countries in different regions represents a quantum leap or a spike from a firm-level perspective, compared to the distance between countries within a region (Flores, Aguilera, Mahdian, \& Vaaler, 2013; Rugman et al., 2011a). Regionalization literature, therefore, often distinguishes between intra-regional and inter-regional diversification. Intra-regional diversification refers to geographical diversification across countries within a single region, whereas inter-regional diversification indicates geographical diversification across countries in the different regions. It is noteworthy that intra-regional diversification may occur in any region in which the firm is already present, including a firm's home region (Qian, Li, \& Rugman, 2013), and that intra- and inter-regional 
diversification is not mutually exclusive to each other. In other words, MNEs can be, at the same time, intra-regionally diversified in some regions while they are inter-regionally diversified across different regions.

The regionalization theory argues that intra-regional diversification provides firms with important advantages over inter-regional diversification (Rugman \& Verbeke, 2005, 2007, 2008b). By expanding into countries in the same region, MNEs can benefit from regional fungibility and increased redeployability of their firm-specific advantages (FSAs) at lower costs as compared to the expansion into countries in different regions (Rugman \& Verbeke, 2005) because the strength of the MNE's FSAs and the spatial transaction costs associated with their transfer and exploitation are substantially moderated by regional boundaries (Arregle, Miller, Hitt, \& Beamish, 2013; Verbeke \& Asmussen, 2016). MNEs can also benefit from lower compounded distances in geographical diversification, in other words, regional similarities among country environments such as formal and informal institutional conditions (Rugman \& Oh, 2013) and among the configurations of firm-level activities such as similar human resource management practices and customer support routines (Edwards, Jalette, \& Tregaskis, 2012). Therefore, an (intra-) regional orientation, deploying resources and capabilities among internal and region-based network, makes a more efficient configuration compared to global diversification (Rugman \& Verbeke, 2001, 2008a; Verbeke \& Asmussen, 2016).

\subsection{Regionalization and expatriate utilization}

A body of literature has demonstrated the role of the region in various aspects of MNE activities (Arregle et al., 2013; Banalieva \& Dhanaraj, 2013), strategies (Nguyen, 2014; Oh \& Rugman, 2012), management (Ambos \& Schlegelmilch, 2010; Chakravarty, Hsieh, Schotter, \& Beamish, 2017) and performance (Oh \& Contractor, 2014; Qian, Khoury, Peng, \& Qian, 
2010). While these studies have significantly advanced our understanding of how MNEs operate and perform in a semi-globalized world, the extant literature has paid little attention to how regionalization affects the MNE's expatriate utilization. However, this is an important question that deserves more research because as the degree of internationalization increases, MNEs face growing constraints in managerial resources, which drive them to adjust and economize on their use of managerial resources (Hutzschenreuter, Voll, \& Verbeke, 2011; Penrose, 1959).

Expatriates are crucial managerial resources that effectively fulfill a range of parenting activities. Based on both resource-based view and transaction cost economics, many scholars have demonstrated that expatriates provide MNEs with an important control and coordination mechanism over geographically dispersed MNE activities, compared to local employees (Benito, Tomassen, Bonache-Pérez, \& Pla-Barber, 2005; Harzing, 2001a; Tan \& Mahoney, 2006). However, expatriates are also limited resources that are increasingly associated with supply issues (Collings et al., 2007). The excessive use of expatriates may also restrain MNEs from capitalizing on local diversity (Tarique et al., 2006) and significantly increase operational costs (Sparrow, Brewster, \& Chung, 2016). Given the trade-off, MNEs must determine the appropriate level of expatriate utilization for their international management and allocate expatriates to overseas subsidiaries considering different contingencies presented by individual subsidiary contexts (Nohria \& Ghoshal, 1994).

Most of the literature has examined the appropriate expatriate staffing level at the subsidiary level, while little attention has been paid to the expatriate utilization at the aggregate MNE level. This constitutes a major deficit in our understanding of the MNE's expatriate utilization because MNE headquarters that simultaneously manages multiple subsidiaries tends to make a resource allocation decision considering organizational contingencies presented by the entire portfolio of subsidiaries rather than the individual subsidiary context (Nohria \& 
Ghoshal, 1997).

In this study, I view expatriate staffing decision as a managerial resource allocation decision made by headquarters while regarding the degree of internationalization as a major organizational contingency represented by the entire subsidiary portfolio. I argue that the degree of the MNE's internationalization has to do with its overall use of expatriates for international management. Specifically, drawing on regionalization theory, this paper contends that regional diversification forms an important boundary condition for the level of expatriate utilization.

Regionalization theory predicts that MNEs with varying degrees of intra- and interregional diversification need to adjust their control and coordination mechanisms because they have different learning opportunities while facing different degrees of organizational and environmental complexities (Arregle et al., 2013; Qian et al., 2010; Rugman \& Verbeke, 2007; Verbeke et al., 2009). While MNEs generally utilize a combination of three control and coordination mechanisms, namely, centralization, formalization and socialization, for international management (Ghoshal \& Nohria, 1989), the use of expatriates is closely related with all three mechanisms. Specifically, expatriates provide a key administrative measure of socialization and a powerful formula for information system development that play sophisticated coordination roles. In addition, they support the management of bureaucratic rules and systems (i.e., formalization) and promote the centralization of decision-making including direct surveillances over subsidiaries (Edström \& Galbraith, 1977; Harzing, 2001a; Martinez \& Jarillo, 1989). Therefore, this study postulates that the overall use of expatriates by MNEs will vary upon the degrees of their intra- and inter-regional diversification.

\section{Hypotheses development}

\subsection{Intra-regional diversification and expatriate utilization}


When an MNE increases its geographic scope, it incurs additional costs because contractual and operational risks are amplified due to various environmental differences across borders. Therefore, geographic scope is a critical element for internationalization decisions and is closely related with the MNE's capability to control and coordinate international activities (Rugman \& Verbeke, 2005). Escalating geographic diversification can greatly increase transaction costs, managerial information-processing demands, and control and coordination failures (Hitt, Hoskisson, \& Ireland, 1994). Relying on environmental similarity and geographical proximity among countries within a region, intra-regional diversification allows MNEs to effectively reduce such additional costs associated with foreign expansions as well as the managerial complexity of coordination, communication and knowledge sharing across subsidiaries (Arregle, Beamish, \& Hebert, 2009; Rugman \& Verbeke, 2005). Specifically, expanding into a new country requires high managerial information-processing demands and the associated costs, and hence, increases control and coordination problems at headquarters (Hitt, Hoskisson, \& Kim, 1997; Kostova \& Zaheer, 1999). Environmental commonality across countries within the same region can minimize such problems because knowledge and experience gained from one country can be exploited throughout the same region with relatively low costs (Arregle et al., 2013). Geographical proximity among countries within a region also facilitates the transmission of knowledge and information across subsidiaries, and thereby, helps MNEs to decrease information asymmetries and maintain the reliability of their operations (e.g., by curbing opportunism) (Arregle et al., 2009).

Therefore, intra-regional diversification enables MNEs to reduce the associated bounded rationality and bounded reliability challenges within a region, which in turn decreases control and coordination complexity faced by headquarters (Rugman \& Verbeke, 2005, 2007). Consequently, intra-regional diversification permits MNEs to economize on the costs, uncertainty and coordination problems associated with regional management with less 
managerial resources and greatly decreases the MNE's need for intensive use of expatriates which accompanies high operational costs. In addition, geographical proximity makes it easier to utilize alternative forms of international assignment (i.e., short-term assignments, international business travelers, etc.) other than expatriates, which may effectively reduce operational costs and other expatriation-associated problems (Collings et al., 2007). Taken together, the above discussion suggests the following hypothesis:

Hypothesis 1: Intra-regional diversification is negatively related with the level of expatriate utilization by MNEs

\subsection{Inter-regional diversification and expatriate utilization}

Inter-regional diversification increases the MNE's growth potential, but at high risks and costs (Qian, Li, Li, \& Qian, 2008). It exposes MNEs to different environments that may help them to maximize opportunities to successfully arbitrage and exploit market differences (Delios \& Beamish, 2005) and that may allow them to source and combine new and different international resources and capabilities (Almeida, 1996; Kotabe \& Mudambi, 2009). However, such potential benefits can only be realized with the MNE's managerial capability to implement effective inter-regional coordination and arbitraging mechanisms (Goerzen \& Beamish, 2003; Kirca et al., 2011). The initiatives and benefits of inter-regional diversification are often counteracted by lack of management experience and expertise (Qian \& Li, 2002; Qian et al., 2008).

MNEs with a higher level of inter-regional diversification usually face greater difficulties in dealing successfully with organizational and environmental complexity as they are often fraught with bounded rationality and bounded reliability challenges beyond those associated with home regional expansion (Rugman \& Verbeke, 2007; Verbeke \& Asmussen, 2016). They must contend with the complex situation of managing a multicultural workforce that serves 
distinctly different customer markets (Edwards et al., 2012; Gomes \& Ramaswamy, 1999). Managing diverse market environments in different regions imposes an increasing burden on top management, as the institutional foundations in various regions are highly dynamic and may shift rapidly (Hitt et al., 1997). Cultural diversity brings about various problems of communication, control and coordination (Gomez-Mejia \& Palich, 1997) while institutional diversity increases the risk and uncertainty for the decision-making process (Kostova \& Zaheer, 1999). The marginal costs and complexity of control and coordination increase rapidly as MNEs diversify further and further away from their familiar environments.

Therefore, inter-regional diversification increases the MNE's need for more quality management and sophisticated parenting activities to cope with greater managerial complexity. This leads MNEs to utilize more expatriates to ensure effective control and coordination over widely dispersed operations. This suggests the following hypothesis:

Hypothesis 2: Inter-regional diversification is positively related with the level of expatriate utilization by MNEs

\subsection{The role of subsidiary value chain activities}

The predicted relationships between the degree of intra- and inter-regional diversification and the level of expatriate utilization can vary depending on subsidiary value chain activities. Specifically, I argue that the MNE's use of expatriates in manufacturing subsidiaries is more invariable, compared to that in downstream subsidiaries, regardless of the degree of geographical diversification.

Managing manufacturing subsidiaries (i.e., factories) in foreign locations generally requires much greater resource commitment and more frequent intra-firm transfer than managing downstream subsidiaries, and hence, it commands much tighter control from headquarters (Bartlett, Ghoshal, \& Birkinshaw, 2003; Belderbos \& Heijltjes, 2005; Johanson 
\& Vahlne, 1977; Taggart \& Hood, 1999). Achieving coordination of an interdependent global manufacturing system requires strong control over the operations of different national subsidiaries. In general, headquarters make central decisions for the various subsidiaries as to what and how much they should produce as well as how their output should be priced for transfer between operations (Benito, 1996; Hill, Hwang, \& Kim, 1990). Moreover, manufacturing activities involve various technological knowledge embodied in research and development (R\&D), production process, special tools and machinery, and proprietary knowhow that must be effectively transferred to foreign locations (Fang, Jiang, Makino, \& Beamish, 2010; Teece, 1977) and protected from unintended spillovers (Alcacer, 2006). Therefore, ensuring close control and monitoring of manufacturing subsidiaries is crucial for $\mathrm{MNE}$ headquarters (Delios \& Henisz, 2003; Mezias, 2002). Expatriates in manufacturing subsidiaries, both managers and technical staff, play pivotal roles in protecting proprietary knowledge (Berry, 2017) and coordinating global production networks by maintaining intensive liaison with headquarters and the mother plant and by ensuring quality control and product consistency (Belderbos \& Heijltjes, 2005; Whitley, Morgan, Kelly, \& Sharpe, 2003). On the contrary, downstream activities such as sales and service are highly sensitive to cultural differences and often require adaptation before being applied successfully to the local market (Hewett, Roth, \& Roth, 2003; Simonin, 1999). Sales and service subsidiaries require more local marketoriented knowledge and local business connections rather than strong control from headquarters, and hence, they tend to value more the contribution of host country managers rather than expatriates who tend to have less commitment to local adaptations (Fang et al., 2010; Harzing, 1999).

Therefore, the use of expatriates in manufacturing subsidiaries is relatively intact, while the use of expatriates in downstream subsidiaries is more flexible depending on different contingencies presented by the degree of geographical diversification. This suggests that the 
above-predicted relationships between the degree of intra- and inter-regional diversification and the level of expatriate utilization are more likely to be evident in downstream subsidiaries while they are weak or less likely to be observable in manufacturing subsidiaries. Thus, the following hypothesis is formed:

Hypothesis 3: Subsidiary value chain activities moderates the relationship between the degree of intra- and inter-regional diversification and the level of expatriate utilization by MNEs, such that the level of expatriate utilization depending on the degree of intra- and interregional diversification is less variable in manufacturing subsidiaries than in downstream subsidiaries.

\section{Methodology}

\subsection{Data and sample}

I tested the hypotheses using Korean MNEs that provide an appropriate setting for this study. Korea is one of the leading sources of foreign direct investment (FDI) in the world. Korean MNEs operate in various industries across many countries and regions, and they commonly utilize expatriates as a control and coordination mechanism over overseas subsidiaries (Kim \& Tung, 2013; Tung, Paik, \& Bae, 2013). A cross-sectional MNE-level dataset was built by combining subsidiary data from the 'Overseas Korean Business Directory (2011-2012) ' published by KOTRA (Korea Trade-Investment Promotion Agency) with MNElevel data collected from 'Kis-value' database provided by NICE (National Information and Credit Evaluation). I excluded state-owned enterprises and public organizations as they have different management policies from private corporations. To ensure the least level of internationalization, MNEs that have less than six subsidiaries were discarded from the sample (Aharoni, 1971). The hitherto process created a sample of 130 MNEs with 1,996 subsidiaries. While this constitutes a full sample of this study, I created two subsamples to test for the 
differences across subsidiary value chain activities by separating manufacturing subsidiaries and downstream subsidiaries. The manufacturing subsidiary sample consists of 80 MNEs and their 375 manufacturing subsidiaries operating in 42 countries. The downstream subsidiary sample consists of 124 MNEs which includes 1,621 subsidiaries (i.e., 469 sales subsidiaries, 445 service subsidiaries and 707 branches) operating in 76 host countries. The overall demographics of the sample are described in Table 1.

Insert Table 1 about here

\subsection{Measurement of variables}

\subsubsection{Dependent variable}

The level of expatriate utilization was measured at the MNE level by calculating the average of the expatriate ratio in all constituent subsidiaries, while the expatriate ratio in each subsidiary was measured by the proportion of the number of expatriates to the total number of subsidiary employees (Gaur et al., 2007; Gong, 2003).

\subsubsection{Independent variable}

I used 'entropy' measures to proxy the degree of intra- and inter-regional diversification, which not only captures the extent to which MNE operations are dispersed across foreign countries within regions but also quantifies the dispersion of MNE operations across different regions (Hitt, Tihanyi, Miller, \& Connelly, 2006; Qian et al., 2008). As the main focus of this study is on the 'breadth' of international diversification, I used scope measures rather than scale measures to calculate the entropy index (Rugman \& Oh, 2013). Many researchers and organizations (e.g., World Bank, OECD, United Nations) have projected various regional 
classifications including the 'Triad' (North America, Europe and Asia) (Ohmae, 1985; Rugman \& Verbeke, 2004) and much finer classifications (see Aguilera, Flores, and Vaaler (2007) for a review). In this study, I grouped countries into seven geographic regions (i.e., Asia, Africa, Europe, the Middle East, North America, Oceania and South America) based on the geographic and cultural distances that create the most significant barriers to international business (Delios \& Beamish, 2005; Håkanson \& Ambos, 2010). This classification is appropriate for this study because the well-known Triad may not sufficiently capture the complexity associated with managing different regions, whereas much finer classification may not sufficiently distinguish the regional effect from the country effect.

The entropy measure of intra-regional diversification that captures geographic diversification across countries within a region is constructed by a two-step procedure (Qian et al., 2010; Qian et al., 2013). I first consider both the number of subsidiaries (NSB) and the number of operating countries (NOC) within each region (INTRA $\mathrm{a}_{\mathrm{a}}$ ), and then NSB and NOC in all regions by adding each of them (INTRA $\left.A_{j}\right)$. The formula of INTRA $A_{a}$ is formed as follows:

$$
\operatorname{INTRA}_{a}=\sum_{i \in a} P_{i a}^{a} \ln \left(1 / P_{i a}^{a}\right)
$$

where $P_{i a}^{a}$ for INTRANSB is the proportion of the NSB in the $i^{t h}$ country to the total NSB in the $a^{\text {th }}$ region in the sample, and $P_{i a}^{a}$ for INTRANOC is the proportion of the NOC to the total NOC in the $a^{\text {th }}$ region in the sample. If there are $\mathrm{j}$ regions all together, then INTRA $_{\mathrm{j}}$ is the weighted average of $\operatorname{INTRA}_{a j}(\mathrm{a} \in \mathrm{j})$, while the weight is previously defined $P_{a j}^{j}$. The formula of INTRA $A_{j}$ is formed as follows:

$$
\operatorname{INTR} A_{j}=\sum_{a=1}^{j} P_{a j}^{j} \times I N T R A_{a j}
$$

While the hitherto process creates two scope entropy measures, i.e., INTRA NSB $_{\text {and INTRA }}$ NOC, I created a composite measure for intra-regional diversification by averaging them. The 
correlation between the two measures was 0.98 .

The entropy measure of inter-regional diversification that captures geographic diversification across different regions is constructed as follows:

$$
I N T E R=\sum_{k=1}^{m} P^{k} \ln \left(1 / P^{k}\right)
$$

where $m$ is the number of regions in which a firm has subsidiaries or operating countries, and $P^{k}$ is the proportion of NSB or NOC in the $k^{t h}$ region to the total NSB or NOC in all regions. In this study, $m$ equals 7 as I grouped countries into seven regions. I also integrated two scope entropy measures, i.e., INTER NSB $_{\text {and INTER }}$ NOC into a composite measure by averaging them. The correlation between the two measures was 0.97 .

\subsubsection{Control variable}

I controlled for various firm- and country-level variables following prior literature on expatriate staffing. (1) MNE size measured by the sales amount, (2) MNE age and (3) MNE performance proxied by ROA (return on asset) were included as control variables. This study also controlled for (4) the depth (the scale measure) of internationalization proxied by the proportion of the size (measured by the number of employees) of foreign operations to the size of total MNE operations (Downes \& Thomas, 2000) and (5) the MNE's international experience operationalized by the total number of subsidiary years of experience accumulated in all subsidiaries in the world (Peng \& Beamish, 2014). I also controlled for the host country environment where the MNE subsidiaries are located. (6) Cultural distance measured by the average of cultural distance indices, which were calculated following Kogut and Singh (1988) formula, between Korea and all of the host countries, and (7) the average of host-country GDP based on data from the World Development Indicators by the World Bank were added as control variables. The institution development was controlled using (8) the average score of Economic 
Freedom Index of all host countries provided by the Heritage Foundation (Peng \& Beamish, 2014). In addition, I also controlled for institutional quality using (9) bureaucracy quality and (10) law and order indices from the International Country Risk Guide (Hyun et al., 2015). I also controlled for (11) the average subsidiary size of the MNE by computing the average number of employees in all constituent subsidiaries and (12) MNE ownership over subsidiaries measured by the ratio of the number of wholly-owned subsidiaries to the total number of subsidiaries. Finally, (13) The industry effect was also controlled by adding a dummy variable coded 1 for MNEs that belong to manufacturing industries in Korean standard industrial classification and 0 for others.

\section{Results}

Table 2 presents the descriptive statistics and correlation matrix for the variables used in the analyses. Multicollinearity seems not to exist as the bivariate correlation coefficients are generally low across all variables. I also checked the variance inflation factors (VIFs), and all variables showed lower values (i.e., the highest value was 5.4) than the usual cutoff of 10 (Hair, Tatham, Anderson, \& Black, 2006). Therefore, I concluded that no serious multicollinearity problem was involved in the analyses.

Insert Table 2 about here

Table 3 shows the results of hypotheses testing using a series of hierarchical ordinary least square (OLS) regression analysis. Model 1-4 present the result of the full sample analysis, which includes both manufacturing and downstream subsidiaries. Model 1 is a baseline model with control variables only. The result indicates that, while larger MNEs (in terms of sales) tend to use more expatriate, more internationalized MNEs (in terms of the depth of 
internationalization and international experience) and highly performing firms are likely to utilize fewer expatriates. These effects remain stable in subsequent models. Model 2-4 present the effects of intra- and inter-regional diversification. Intra-regional diversification is not found to be significantly related with the level of expatriate utilization, rejecting hypothesis 1 (Model 2). Inter-regional diversification shows a strong positive relationship with the level of expatriate utilization, supporting hypothesis 2 (Model 3). In model 4, intra-regional diversification becomes statistically significant while showing a negative relationship as predicted, when it is added together with inter-regional diversification. However, this result should be interpreted with caution. I believe several confounding effects of predictors (i.e., multicollinearity and suppression) account for this change, but as revealed in the subsequent analysis, decomposing subsidiary value chain activities provides much clearer ideas about the regional effects on expatriate utilization by MNEs.

Model 5-8 show the result of the manufacturing subsidiary sample analysis. Model 5 is a baseline model with control variables only. It is shown that older MNEs tend to use fewer expatriates in manufacturing subsidiaries and so do the firms belong to the manufacturing industry. These effects remain stable in all subsequent models. However, both intra- and interregional diversification show no significant relationships with the level of expatriate utilization, indicating that the use of expatriates by MNEs in manufacturing subsidiaries is not related with the degree of geographical diversification of their manufacturing subsidiaries.

Finally, Model 9-12 present the result of the downstream subsidiary sample analysis. Model 9 shows a baseline model with control variables only. The result reveals that, similar to the full sample analysis, larger MNEs (in terms of sales) tend to use more expatriate, while more internationalized MNEs (in terms of the depth of internationalization and international experience) and more profitable MNEs are likely to utilize fewer expatriates in their downstream subsidiaries. It is also shown that MNEs with larger subsidiaries tend to use fewer 
expatriates. Model 10 presents that intra-regional diversification of downstream subsidiaries has a strong negative relationship with the level of expatriate utilization in downstream subsidiaries, while Model 11 shows the opposite result that inter-regional diversification is strongly positively associated with the level of expatriate utilization. Model 12 confirms that these relationships remain stable.

Overall, the results from the three sets of analyses disclose that hypotheses 1 and 2 are partially supported: expatriate utilization by MNEs is negatively associated with the degree of intra-regional diversification while it is positively related to the degree of inter-regional diversification only in downstream subsidiaries. These relationships are found to be insignificant in manufacturing subsidiaries. These results lend support to hypothesis 3 .

As a robustness check, I control for the industry impact using 8 industry dummies classified by Korean standard industry classification (i.e., manufacturing, finance, transportation, retail, construction, professional, information and communication, electricity and water supply, others), instead of a binary dummy variable. With more specified industry dummies, all hypothesized relationships remain robust. I further test my hypotheses using Tobit regression as the dependent variable has lower and upper limits. I find almost identical results from both analyses. Therefore, the findings from this study are generally robust and reliable.

Insert Table 3 about here

\section{Discussion}

This study explores in what circumstance the level of expatriate utilization varies at the aggregate MNE level. I build on the view of expatriate utilization as a managerial resource allocation by headquarters that reflects not only different contingencies presented by the 
individual subsidiary context but also the MNE's overall organizational contingency created by the entire subsidiary portfolio (Nohria \& Ghoshal, 1997). The degree of internationalization constitutes the unique organizational contingency of the MNE (Ghoshal \& Westney, 1993) that determines the level of managerial complexity facing MNEs, and hence, influences the desired level of control and coordination over subsidiaries (Kostova \& Zaheer, 1999; Verbeke et al., 2009). This study examines how the degree of internationalization is associated with MNE's use of expatriates that provide a key control and coordination mechanism to manage international operations (Boyacigiller, 1990; Harzing, 2001a; Tan \& Mahoney, 2006).

This paper draws on regionalization theory to argue that the degree of intra- and interregional diversification has to do with the overall use of expatriates in MNEs. Intra-regional diversification allows MNEs to reduce the bounded rationality and bounded reliability constraints associated with international operations, whereas inter-regional diversification increases such constraints and poses greater challenges of control and coordination (Rugman \& Verbeke, 2005, 2007). In general, the findings of this study demonstrate that the degree of inter-regional diversification is significantly related with the level of expatriate utilization by MNEs. Interestingly, however, the results also reveal such relationship is moderated by subsidiary value chain activities. Depending on the varying degrees of intra- and inter-regional diversification, MNEs utilize more or fewer expatriates in their downstream subsidiaries but they do not make changes in their use of expatriates in manufacturing subsidiaries.

The findings of this study make several important contributions. First, this study extends our understanding of the role of the region in international management particularly as to the level of expatriate utilization. Regionalization literature has shed light on the role of geographical regions in the MNE's international strategies (Rugman \& Verbeke, 2008a; Verbeke \& Asmussen, 2016), investment decisions (Arregle et al., 2009; Arregle et al., 2013) and performance (Oh \& Contractor, 2014; Qian et al., 2010) but placed little attention to how 
regionalization affects the MNE's management decisions such as expatriate utilization. However, the link between regional diversification and the management is important because it is not merely the degree of internationalization, but how MNEs manage and coordinate their international activities that renders geographical diversification a viable strategy with positive performance outcomes (Goerzen \& Beamish, 2003; Kirca et al., 2011; Kotabe, Srinivasan, \& Aulakh, 2002). In particular, as MNEs expand into multiple locations, they face greater managerial resource constraints, which drive them to adjust and economize on their use of managerial resources such as expatriates (Hutzschenreuter et al., 2011). This study adds to the literature by proving this linkage between the degree of regional diversification and expatriate utilization. It is revealed that inter-regional diversification is strongly positively associated with expatriate utilization by MNEs, indicating that, ceteris paribus, more inter-regionally diversified MNEs utilize more expatriates for their international management. This result confirms the role of the geographic region on the MNE's management as predicted by regionalization theory (Rugman \& Verbeke, 2005, 2007). The intra-regional diversification is not found to be significantly related with the level of expatriate utilization in the full sample analysis, but the subsequent analysis of subsamples divided by subsidiary value chain activities provides clearer insights into the regional effects on the MNE's use of expatriates.

The second contribution of this paper lies in its investigation on the role of subsidiary value chain activities in the MNE's expatriate utilization. The results of subsample analyses suggest that MNEs tend not to adjust their use of expatriates in manufacturing subsidiaries depending on geographical diversification. In other words, MNEs maintain the level of expatriate utilization in manufacturing subsidiaries no matter to what extent their manufacturing subsidiaries are intra-regionally or inter-regionally diversified. On the contrary, MNEs tend to vigorously adjust their use of expatriates in downstream subsidiaries depending on the degrees of intra- and inter-regional diversification: more intra-regionally diversified MNEs utilize 
fewer expatriates while more inter-regional dispersed MNEs use more expatriates. This makes sense when thinking about the different strategic importance of manufacturing and downstream subsidiaries (Chang \& Taylor, 1999) and the nature of knowledge that these subsidiaries deal with (Fang et al., 2010), both of which concern the desired level of control and coordination over subsidiaries (Benito, 1996; Hill et al., 1990).

Recent literature suggests that the influence of subsidiary value chain activities should be considered in assessing the role of regionalization (Mudambi \& Puck, 2016; Rugman, Verbeke, \& Yuan, 2011b; Verbeke \& Asmussen, 2016). Although regionalization literature has increasingly presented strong evidence on the regional nature of multinational activities, its findings may not capture the full array of the MNE's international activities. Extant literature has mainly focused on the geographical location of downstream activities while relatively disregarding other upstream activities. However, the geographical footprint of the MNE can be much more dispersed than it is assumed by regionalization literature that has typically used scale measures (such as sales or assets) to examine the geographical dispersion of MNE activities (Mudambi \& Puck, 2016). The footprint and the related organizational arrangement may be vastly different for each value chain activity, and regional strategy may be more important for some value chain activities than others. This paper confirms this idea by showing that the regional effects on expatriate utilization actually vary depending on the subsidiary value chain activities.

This paper also provides important empirical implications to the MNE staffing literature. First, this study explores the level of expatriate utilization at the aggregate MNE level. This is a new and important approach which complements the current focus of the extant literature on examining the appropriate expatriate staffing levels at the individual subsidiary level. Second, this paper reveals that distinguishing subsidiary value chain activities is essential when using the expatriate ratio (i.e., the number of expatriates divided by the total number of subsidiary 
employees) to measure the level of expatriate utilization. Technically, the usual range of expatriate staffing levels is much lower in manufacturing subsidiaries than in downstream subsidiaries, because the total number of subsidiary employees is usually very high in manufacturing subsidiaries than that of downstream subsidiaries. The sample used in this study confirms such tendency. On average, the size of manufacturing subsidiaries measured by the total number of subsidiary employees was 15 times bigger than the average of downstream subsidiaries, and thus, the level of expatriate utilization measured by the ratio of the number of expatriate to the total number of subsidiary employees was only one-seventh (see Table 1 for more details). This paper suggests that controlling for the impact of subsidiary value chain activities is crucial for any expatriate staffing research to adjust for the potential confounding effect.

Finally, this paper provides some practical implications for managers of MNEs. It becomes increasingly important to establish an effective control and coordination mechanism to manage a geographically dispersed organization. One of the key challenges is to make the appropriate use of expatriates. Expatriates are limited managerial resources that are increasingly associated with supply problems (Collings et al., 2007) because, like other managerial resources, they cannot be increased upon the necessity in the short run (Penrose, 1959). Therefore, managers should consider expatriation decisions as a resource allocation decision and they need to recognize the regional effects as well as the impact of subsidiary value chain activities when devising expatriation strategies. Specifically, the MNE's FDI decisions may incur different marginal costs in terms of managerial complexity and coordination difficulties along the regional boundary. The findings of this study suggest that managers should understand that this may further influence the desired level of expatriate utilization which has mainly to do with their downstream subsidiaries.

This study has limitations and several suggestions for future research. First, the empirical 
analysis considers Korean MNEs only. Other country samples may utilize expatriates in different ways, and the results from this study may not generalize in MNEs from other countries. Korean MNEs tend to have a strong ethnocentric corporate culture, which makes the use of expatriates more likely for overseas management compared to Western MNEs. However, such a home country effect may be minimal because there has been substantial convergence of Western management with Korean management style including international staffing and expatriation practices (Chung, Sparrow, \& Bozkurt, 2014; Kim \& Tung, 2013; Tung et al., 2013).

Second, this study used scope measures to produce entropy metrics for empirical analysis. However, there can be a discrepancy between scale and scope measures such that scope measures usually indicate more geographic dispersion less concentrated in home regions (Rugman \& Oh, 2013). Scope measures are more appropriate in this research because it mainly aims to capture the distances and diversity involved in international management. However, additional research that uses scale measures to create entropy metrics may provide some complementary implications.

Third, the findings of this study indicate that intra- and inter-regional diversification has a conflicting relationship with the level of expatriate utilization by MNEs. These results suggest that the MNE's use of expatriates may vary depending on the combination of their intra- and inter-regional diversification. As noted earlier, intra- and inter-regional diversification is not incompatible with each other, and MNEs can be intra-regionally diversified as well as interregionally diversified at the same time. Therefore, additional research on such conflicting relationships may also provide a deeper insight into the regional effects on the MNE's expatriate utilization.

Fourth, this study reveals that the expatriate utilization by MNEs is different between manufacturing subsidiaries and downstream subsidiaries. While such distinction constitutes an 
important approach, my results showed that most of the control variables are not significantly related with the expatriate utilization in manufacturing subsidiaries. This may be partially associated with the fact that manufacturing subsidiaries are highly concentrated in Asia, but I believe future research that investigates the determinants of the level of expatriate utilization in manufacturing subsidiaries will greatly advance our knowledge of the MNE's expatriate utilization.

Finally, future research may extend the linkage between intra- and inter-regional diversification and expatriate utilization further to MNE performance, examining the mediating role of expatriation in the multinationality-performance relationship. Such research could contribute to the IB literature by substantiating a notable but rarely tested argument that the management of multinational organizations actually matters to MNE performance rather than the degree of international diversification (Kirca et al., 2011; Verbeke \& Forootan, 2012).

\section{Conclusion}

This study is among the first to examine the level of expatriate utilization at the aggregate MNE level, particularly its relationships with the degree of regional diversification and subsidiary value chain activities. My main argument is that MNEs utilize more or fewer expatriates depending on the degree of regional diversification and that such regional effects on expatriate utilization are contingent on subsidiary value chain activities. Overall, the arguments and findings in this paper provide a more nuanced understanding of how MNEs manage a geographically dispersed organization in a semi-globalized world than has been addressed in extant literature while highlighting opportunities for future research to extend the study of the role of geographic regions in the management and coordination of various MNE activities. 


\section{References}

Aguilera, R. V., Flores, R., \& Vaaler, P. M. 2007. Is it all a matter of grouping? Examining the regional effect in global strategy research. In S. Tallman (Ed.), International strategic management: A new generation: 209-228. Northampton, MA: Edward Elgar.

Aharoni, Y. 1971. Definition of a multinational corporation. Quarterly Review of Economics and Business, 11(3): 27-37.

Alcacer, J. 2006. Location choices across the value chain: How activity and capability influence collocation. Management Science, 52(10): 1457-1471.

Almeida, P. 1996. Knowledge Sourcing by Foreign Multinationals: Patent Citation Analysis in the U.S. Semiconductor Industry. Strategic Management Journal, 17(Winter Special Issue): 155-165.

Ambos, B., \& Schlegelmilch, B. 2010. The new role of regional management. London, UK: Palgrave Macmillan.

Arregle, J. L., Beamish, P. W., \& Hebert, L. 2009. The regional dimension of MNEs' foreign subsidiary localization. Journal of International Business Studies, 40(1): 86-107.

Arregle, J. L., Miller, T. L., Hitt, M. A., \& Beamish, P. W. 2013. Do regions matter? An integrated institutional and semiglobalization perspective on the internationalization of MNEs. Strategic Management Journal, 34(8): 910-934.

Aycan, Z., \& Kanungo, R. N. 1997. Current issues and future challenges in expatriate management. In Z. Aycan (Ed.), Expatriate management: Theory and research: 245260. Greenwich, CT: JAI Press.

Banalieva, E. R., \& Dhanaraj, C. 2013. Home-region orientation in international expansion strategies. Journal of International Business Studies, 44(2): 89-116.

Bartlett, C. A., Ghoshal, S., \& Birkinshaw, J. M. 2003. Transnational management. New York: McGraw-Hill.

Beamish, P. W., \& Inkpen, A. C. 1998. Japanese firms and the decline of the Japanese expatriate. Journal of World Business, 33(1): 35-50.

Belderbos, R. A., \& Heijltjes, M. L. G. 2005. The determinants of expatriate staffing by Japanese multinationals in Asia: Control, learning and vertical business groups. Journal of International Business Studies, 36(3): 341-354.

Benito, G. R. 1996. Ownership structures of Norwegian foreign subsidiaries in manufacturing. The International Trade Journal, 10(2): 157-198.

Benito, G. R., Tomassen, S., Bonache-Pérez, J., \& Pla-Barber, J. 2005. A transaction cost 
analysis of staffing decisions in international operations. Scandinavian Journal of Management, 21(1): 101-126.

Berry, H. 2017. Managing valuable knowledge in weak IP protection countries. Journal of International Business Studies, 48(7): 787-807.

Berry, H., Guillen, M. F., \& Zhou, N. 2010. An institutional approach to cross-national distance. Journal of International Business Studies, 41(9): 1460-1480.

Bonache, J., Brewster, C., \& Suutari, V. 2001. Expatriation: A developing research agenda. Thunderbird International Business Review, 43(1): 3-20.

Boyacigiller, N. 1990. The role of expatriates in the management of interdependence, complexity and risk in multinational corporations. Journal of International Business Studies, 21(3): 357-381.

Chakravarty, D., Hsieh, Y.-Y., Schotter, A. P., \& Beamish, P. W. 2017. Multinational enterprise regional management centres: Characteristics and performance. Journal of World Business, 52(2): 296-311.

Chang, E., \& Taylor, M. S. 1999. Control in multinational corporations (MNCs): The case of Korean manufacturing subsidiaries. Journal of Management, 25(4): 541-565.

Chung, C., Sparrow, P., \& Bozkurt, Ö. 2014. South Korean MNEs' international HRM approach: Hybridization of global standards and local practices. Journal of World Business, 49(4): 549-559.

Collings, D. G., Scullion, H., \& Dowling, P. J. 2009. Global staffing: A review and thematic research agenda. International Journal of Human Resource Management, 20(6): 1253-1272.

Collings, D. G., Scullion, H., \& Morley, M. J. 2007. Changing patterns of global staffing in the multinational enterprise: Challenges to the conventional expatriate assignment and emerging alternatives. Journal of World Business, 42(2): 198-213.

Delios, A., \& Beamish, P. W. 2005. Regional and global strategies of Japanese firms. MIR: Management International Review, 45(1): 19-36.

Delios, A., \& Henisz, W. J. 2003. Policy uncertainty and the sequence of entry by Japanese firms, 1980-1998. Journal of International Business Studies, 34(3): 227-241.

Downes, M., \& Thomas, A. S. 2000. Knowledge transfer through expatriation: The U-curve approach to overseas staffing. Journal of Managerial Issues, 12(2): 131-149.

Edström, A., \& Galbraith, J. R. 1977. Transfer of managers as a coordination and control strategy in multinational organizations. Administrative Science Quarterly, 22(2): 248- 
263.

Edwards, T., Jalette, P., \& Tregaskis, O. 2012. To what extent is there a regional logic in the management of labour in multinational companies? Evidence from Europe and North America. International Journal of Human Resource Management, 23(12): 2468-2490.

Fang, Y. L., Jiang, G. L. F., Makino, S., \& Beamish, P. W. 2010. Multinational firm knowledge, use of expatriates, and foreign subsidiary performance. Journal of Management Studies, 47(1): 27-54.

Flores, R., Aguilera, R. V., Mahdian, A., \& Vaaler, P. M. 2013. How well do supranational regional grouping schemes fit international business research models? Journal of International Business Studies, 44(5): 451-474.

Gaur, A. S., Delios, A., \& Singh, K. 2007. Institutional environments, staffing strategies, and subsidiary performance. Journal of Management, 33(4): 611-636.

Ghemawat, P. 2001. Distance still matters. Harvard Business Review, 79(8): 137-147.

Ghemawat, P. 2003. Semiglobalization and international business strategy. Journal of International Business Studies, 34(2): 138-152.

Ghoshal, S., \& Nohria, N. 1989. Internal differentiation within multinational corporations. Strategic Management Journal, 10(4): 323-337.

Ghoshal, S., \& Westney, D. E. 1993. Organization theory and the multinational corporation. London: Macmillan.

Goerzen, A., \& Beamish, P. W. 2003. Geographic scope and multinational enterprise performance. Strategic Management Journal, 24(13): 1289-1306.

Goerzen, A., \& Beamish, P. W. 2007. The Penrose effect:“Excess” expatriates in multinational enterprises. MIR: Management International Review, 47(2): 221-239.

Gomes, L., \& Ramaswamy, K. 1999. An empirical examination of the form of the relationship between multinationality and performance. Journal of International Business Studies, 30(1): 173-187.

Gomez-Mejia, L. R., \& Palich, L. E. 1997. Cultural diversity and the performance of multinational firms. Journal of International Business Studies: 309-335.

Gong, Y. 2003. Subsidiary staffing in multinational enterprises: Agency, resources, and performance. Academy of Management Journal, 46(6): 728-739.

Guest, D. 1989. Personnel and HRM:Can you tell the difference? Personnel management, 21(1): 48-51.

Hair, J. F., Tatham, R. L., Anderson, R. E., \& Black, W. 2006. Multivariate data analysis. 
Upper Saddle River, NJ: Pearson (Prentice-Hall).

Harzing, A.-W. 1999. Managing the multinationals: An international study of control mechanisms. Cheltenham, U.K.: Edward Elgar.

Harzing, A.-W. 2001a. Of bears, bumble-bees, and spiders: The role of expatriates in controlling foreign subsidiaries. Journal of World Business, 36(4): 366-379.

Harzing, A.-W. 2001b. Who's in charge? An empirical study of executive staffing practices in foreign subsidiaries. Human Resource Management, 40(2): 139-158.

Harzing, A.-W., Pudelko, M., \& Reiche, S. B. 2015. The bridging role of expatriates and inpatriates in knowledge transfer in multinational corporations. Human Resource Management, 55(4): 679-695.

Håkanson, L., \& Ambos, B. 2010. The antecedents of psychic distance. Journal of International Management, 16(3): 195-210.

Hewett, K., Roth, M. S., \& Roth, K. 2003. Conditions influencing headquarters and foreign subsidiary roles in marketing activities and their effects on performance. Journal of International Business Studies, 34(6): 567-585.

Hill, C. W. L., Hwang, P., \& Kim, W. C. 1990. An eclectic theory of the choice of international entry mode. Strategic Management Journal, 11(2): 117-128.

Hitt, M. A., Hoskisson, R. E., \& Ireland, R. D. 1994. A mid-range theory of the interactive effects of international and product diversification on innovation and performance. Journal of Management, 20(2): 297-326.

Hitt, M. A., Hoskisson, R. E., \& Kim, H. 1997. International diversification: Effects on innovation and firm performance in product-diversified firms. Academy of Management Journal, 40(4): 767-798.

Hitt, M. A., Tihanyi, L., Miller, T., \& Connelly, B. 2006. International diversification: Antecedents, outcomes, and moderators. Journal of Management, 32(6): 831-867.

Hutzschenreuter, T., Voll, J. C., \& Verbeke, A. 2011. The impact of added cultural distance and cultural diversity on international expansion patterns: A Penrosean perspective. Journal of Management Studies, 48(2): 305-329.

Hyun, H.-J., Oh, C. H., \& Paik, Y. 2015. Impact of nationality composition in foreign subsidiary on its performance: A case of Korean companies. International Journal of Human Resource Management, 26(6): 806-830.

Johanson, J., \& Vahlne, J.-E. 1977. The internationalization process of the firm: A model of knowledge development and increasing foreign market commitments. Journal of 
International Business Studies, 8(1): 23-32.

Kim, H.-D., \& Tung, R. L. 2013. Opportunities and challenges for expatriates in emerging markets: An exploratory study of Korean expatriates in India. International Journal of Human Resource Management, 24(5): 1029-1050.

Kirca, A. H., Hult, G. T. M., Roth, K., Cavusgil, S. T., Perryy, M. Z., Akdeniz, M. B., Deligonul, S. Z., Mena, J. A., Pollitte, W. A., Hoppner, J. J., Miller, J. C., \& White, R. C. 2011. Firm-specific assets, multinationality, and financial performance: A metaanalytic review and theoretical integration. Academy of Management Journal, 54(1): 47-72.

Kogut, B., \& Singh, H. 1988. The effect of national culture on the choice of entry mode. Journal of International Business Studies, 19(3): 411-432.

Kostova, T., \& Zaheer, S. 1999. Organizational legitimacy under conditions of complexity: The case of the multinational enterprise. Academy of Management Review, 24(1): 6481.

Kotabe, M., \& Mudambi, R. 2009. Global sourcing and value creation: Opportunities and challenges. Journal of International Management, 15(2): 121-125.

Kotabe, M., Srinivasan, S. S., \& Aulakh, P. S. 2002. Multinationality and firm performance: The moderating role of R\&D and marketing capabilities. Journal of International Business Studies, 33(1): 79-97.

Martinez, J. I., \& Jarillo, J. C. 1989. The evolution of research on coordination mechanisms in multinational corporations. Journal of International Business Studies, 20(3): 489514.

Mezias, J. M. 2002. How to identify liabilities of foreignness and assess their effects on multinational corporations. Journal of International Management, 8(3): 265-282.

Mudambi, R., \& Puck, J. 2016. A global value chain analysis of the 'regional strategy'perspective. Journal of Management Studies, 53(6): 1076-1093.

Nguyen, Q. T. 2014. The regional strategies of British multinational subsidiaries in South East Asia. British Journal of Management, 25(S1).

Nohria, N., \& Ghoshal, S. 1994. Differentiated fit and shared values: Alternatives for managing headquarters-subsidiary relations. Strategic Management Journal, 15(6): 491-502.

Nohria, N., \& Ghoshal, S. 1997. The differentiated network: Organizing multinational corporations for value creation. San Francisco, CA: Jossey-Bass Publishers. 
Oh, C. H., \& Contractor, F. 2014. A regional perspective on multinational expansion strategies: Reconsidering the three-stage paradigm. British Journal of Management, 25(Special Issue): S42-S59.

Oh, C. H., \& Rugman, A. M. 2012. Regional integration and the international strategies of large European firms. International Business Review, 21(3): 493-507.

Ohmae, K. 1985. Triad power: The coming shape of global competition. New York: Free Press.

Peng, G. Z., \& Beamish, P. W. 2014. MNC subsidiary size and expatriate control: Resourcedependence and learning perspectives. Journal of World Business, 49(1): 51-62.

Penrose, E. T. 1959. The theory of the growth of the firm. Oxford, UK: Oxford University Press.

Perlmutter, H. V. 1969. The tortuous evolution of the multinational corporation. Columbia Journal of World Business, 4(1): 9-18.

Qian, G., Khoury, T. A., Peng, M. W., \& Qian, Z. M. 2010. The performance implications of intra- and inter-regional geographic diversification. Strategic Management Journal, 31(9): 1018-1030.

Qian, G., \& Li, J. 2002. Multinationality, global market diversification and profitability among the largest US firms. Journal of Business Research, 55(4): 325-335.

Qian, G., Li, L., Li, J., \& Qian, Z. M. 2008. Regional diversification and firm performance. Journal of International Business Studies, 39(2): 197-214.

Qian, G., Li, L., \& Rugman, A. M. 2013. Liability of country foreignness and liability of regional foreignness: Their effects on geographic diversification and firm performance. Journal of International Business Studies, 44(6): 635-647.

Rugman, A. M. 2000. The end of globalization. London: Random House.

Rugman, A. M., \& Oh, C. H. 2013. Why the home region matters: Location and regional multinationals. British Journal of Management, 24(4): 463-479.

Rugman, A. M., \& Verbeke, A. 2001. Subsidiary-specific advantages in multinational enterprises. Strategic Management Journal, 22(3): 237-250.

Rugman, A. M., \& Verbeke, A. 2004. A perspective on regional and global strategies of multinational enterprises. Journal of International Business Studies, 35(1): 3-18.

Rugman, A. M., \& Verbeke, A. 2005. Towards a theory of regional multinationals: A transaction cost economics approach. MIR: Management International Review, 45(Special Issue): 5-17. 
Rugman, A. M., \& Verbeke, A. 2007. Liabilities of regional foreignness and the use of firmlevel versus country-level data: A response to Dunning et al. (2007). Journal of International Business Studies, 38(1): 200-205.

Rugman, A. M., \& Verbeke, A. 2008a. A new perspective on the regional and global strategies of multinational services firms. MIR: Management International Review, 48(4): 397-411.

Rugman, A. M., \& Verbeke, A. 2008b. The theory and practice of regional strategy: A response to Osegowitsch and Sammartino. Journal of International Business Studies, 39(2): 326-332.

Rugman, A. M., Verbeke, A., \& Nguyen, Q. T. K. 2011a. Fifty years of international business theory and beyond. MIR: Management International Review, 51(6): 755-786.

Rugman, A. M., Verbeke, A., \& Yuan, W. 2011b. Re-conceptualizing Bartlett and Ghoshal's classification of national subsidiary roles in the multinational enterprise. Journal of Management Studies, 48(2): 253-277.

Schuler, R. S., Dowling, P. J., \& De Cieri, H. 1993. An integrative framework of strategic international human resource management. Journal of management, 19(2): 419-459.

Shin, D., Hasse, V., \& Schotter, A. 2016. Multinational enterprises within cultural space and place: Integrating cultural distance and cultural tightness-looseness. Academy of Management Journal: amj. 2015.0423.

Simonin, B. L. 1999. Ambiguity and the process of knowledge transfer in strategic alliances. Strategic Management Journal, 20(7): 595-623.

Sparrow, P., Brewster, C., \& Chung, C. 2016. Globalizing human resource management. Abingdon, UK: Routledge.

Taggart, J., \& Hood, N. 1999. Determinants of autonomy in multinational corporation subsidiaries. European Management Journal, 17(2): 226-236.

Tan, D., \& Mahoney, J. T. 2006. Why a multinational firm chooses expatriates: Integrating resource-based, agency and transaction costs perspectives. Journal of Management Studies, 43(3): 457-484.

Tarique, I., Schuler, R., \& Gong, Y. 2006. A model of multinational enterprise subsidiary staffing composition. International Journal of Human Resource Management, 17(2): 207-224.

Teece, D. J. 1977. Technology transfer by multinational firms: The resource cost of transferring technological know-how. The Economic Journal, 87(346): 242-261. 
Tung, R. L., Paik, Y., \& Bae, J. 2013. Korean human resource management in the global context. International Journal of Human Resource Management, 24(5): 905-921.

Verbeke, A., \& Asmussen, C. G. 2016. Global, local, or regional? The locus of MNE strategies. Journal of Management Studies.

Verbeke, A., \& Forootan, M. Z. 2012. How good are multinationality-performance (m-p) empirical studies? Global Strategy Journal, 2(4): 332-344.

Verbeke, A., Li, L., \& Goerzen, A. 2009. Toward more effective research on the multinationality-performance relationship. MIR: Management International Review, 49(2): 149-161.

Whitley, R., Morgan, G., Kelly, W., \& Sharpe, D. 2003. The changing Japanese multinational: Application, adaptation and learning in car manufacturing and financial services. Journal of Management Studies, 40(3): 643-672.

Wright, P. M., \& McMahan, G. C. 1992. Theoretical perspectives for strategic human resource management. Journal of Management, 18(2): 295-320. 
Table 1. Demographics of the sample

\begin{tabular}{lccc}
\hline & Full sample & $\begin{array}{c}\text { Manufacturing } \\
\text { sample }\end{array}$ & $\begin{array}{c}\text { Downstream } \\
\text { sample }\end{array}$ \\
\hline Number of MNEs & 130 & 80 & 124 \\
Number of subsidiaries & 1,996 & 375 & 1,621 \\
Average number of expatriates in a subsidiary & 7.4 & 12.8 & 6.2 \\
Average number of local employees in a subsidiary & 253 & 1,043 & 70 \\
Average expatriate ratio in a subsidiary (\%) & 18.9 & 3.4 & 22.4 \\
Number of operating countries & 77 & 42 & 76 \\
\hline Regional dispersion - subsidiaries (\%) & & & \\
Africa & $48(2 \%)$ & $2(1 \%)$ & $46(3 \%)$ \\
Asia & $1,031(52 \%)$ & $264(70 \%)$ & $767(47 \%)$ \\
Europe & $406(20 \%)$ & $62(17 \%)$ & $344(21 \%)$ \\
Middle East & $121(6 \%)$ & $6(2 \%)$ & $115(7 \%)$ \\
North America & $233(12 \%)$ & $19(5 \%)$ & $214(13 \%)$ \\
Oceania & $40(2 \%)$ & $2(1 \%)$ & $38(2 \%)$ \\
South America & $117(6 \%)$ & $20(5 \%)$ & $97(6 \%)$ \\
\hline Total & $1,996(100 \%)$ & $375(100 \%)$ & $1,621(100 \%)$ \\
\hline
\end{tabular}


Table 2. Descriptive statistics and correlations

(1) Full sample: MNEs with both manufacturing and downstream subsidiaries $(\mathrm{N}=130)$

\begin{tabular}{|c|c|c|c|c|c|c|c|c|c|c|c|c|c|c|c|c|}
\hline Variable & Mean & s.d. & 1 & 2 & 3 & 4 & 5 & 6 & 7 & 8 & 9 & 10 & 11 & 12 & 13 & 14 \\
\hline 1. $\mathrm{ROA}$ & 0.03 & 0.09 & & & & & & & & & & & & & & \\
\hline 2. $\mathrm{ROS}$ & 0.03 & 0.09 & $0.91 *$ & & & & & & & & & & & & & \\
\hline 3. MNE size & 8.35 & 15.06 & 0.08 & 0.06 & & & & & & & & & & & & \\
\hline 4. MNE age & 37.57 & 20.88 & -0.07 & -0.09 & $0.17 *$ & & & & & & & & & & & \\
\hline 5. $\mathrm{R} \& \mathrm{D}$ intensity $(\mathrm{t}-1)$ & 0.01 & 0.02 & $0.14^{*}$ & $0.12 *$ & $0.25^{*}$ & $-0.13 *$ & & & & & & & & & & \\
\hline 6. Advertising intensity $(\mathrm{t}-1)$ & 0.01 & 0.02 & $0.21 *$ & $0.19 *$ & -0.06 & $-0.13 *$ & -0.00 & & & & & & & & & \\
\hline 7. Internationalization (Scale) & 0.39 & 0.28 & -0.10 & $-0.11^{*}$ & $-0.17 *$ & $-0.29 *$ & 0.06 & -0.02 & & & & & & & & \\
\hline 8. Internationalization (Scope) & 12.37 & 10.68 & -0.02 & -0.02 & $0.59 *$ & 0.03 & $0.27 *$ & -0.06 & 0.09 & & & & & & & \\
\hline 9. Average subsidiary size & 4.85 & 1.41 & -0.02 & -0.05 & 0.08 & $-0.21 *$ & $0.21^{*}$ & -0.02 & $0.68^{*}$ & -0.03 & & & & & & \\
\hline 10. International experience & 5.16 & 0.91 & -0.10 & -0.09 & $0.40^{*}$ & $0.22 *$ & $0.13^{*}$ & $-0.14^{*}$ & -0.01 & $0.83 *$ & $-0.11^{*}$ & & & & & \\
\hline 11. Economic freedom & 63.36 & 4.30 & 0.02 & 0.04 & 0.09 & $0.13 *$ & $0.16^{*}$ & 0.03 & $-0.47^{*}$ & $0.15^{*}$ & $-0.43 *$ & $0.23 *$ & & & & \\
\hline 12. Population & 419.53 & 215.55 & $0.20 *$ & $0.18^{*}$ & $-0.14^{*}$ & 0.01 & -0.00 & $0.16^{*}$ & -0.03 & $-0.27^{*}$ & -0.04 & $-0.14^{*}$ & $-0.26^{*}$ & & & \\
\hline 13. Manufacturing subsidiaries & 0.25 & 0.29 & 0.07 & 0.05 & $-0.16^{*}$ & $-0.19 *$ & $0.12 *$ & $-0.12 *$ & $0.59 *$ & $-0.28 *$ & $0.66^{*}$ & $-0.32 *$ & $-0.46^{*}$ & $0.17 *$ & & \\
\hline 14. Power structure & 0.33 & 0.20 & $-0.10^{*}$ & $-0.12 *$ & -0.08 & 0.01 & 0.02 & 0.01 & -0.09 & $-0.32 *$ & $0.16^{*}$ & $-0.34^{*}$ & $0.11^{*}$ & -0.08 & -0.06 & \\
\hline 15. Expatriate utilization & 21.08 & 12.42 & -0.06 & -0.04 & $0.19 *$ & $0.22 *$ & $-0.16^{*}$ & -0.09 & $-0.60^{*}$ & -0.03 & $-0.44^{*}$ & 0.02 & $0.32 *$ & $-0.21 *$ & $-0.47 *$ & $0.33 *$ \\
\hline
\end{tabular}


(2) Manufacturing sample: MNEs with only manufacturing subsidiaries $(\mathrm{N}=80)$

\begin{tabular}{|c|c|c|c|c|c|c|c|c|c|c|c|c|c|c|c|c|}
\hline Variable & Mean & s.d. & 1 & 2 & 3 & 4 & 5 & 6 & 7 & 8 & 9 & 10 & 11 & 12 & 13 & 14 \\
\hline 1. MNE size & 8.53 & 18.09 & & & & & & & & & & & & & & \\
\hline 2. MNE age & 42.90 & 15.59 & 0.10 & & & & & & & & & & & & & \\
\hline 3. MNE ROA & 4.70 & 5.33 & 0.14 & -0.27 & & & & & & & & & & & & \\
\hline 4. Depth of Internationalization & 0.45 & 0.28 & -0.22 & -0.30 & -0.03 & & & & & & & & & & & \\
\hline 5. International experience & 53.54 & 58.79 & 0.58 & 0.06 & 0.06 & 0.17 & & & & & & & & & & \\
\hline 6. Cultural distance & 2.05 & 0.75 & -0.03 & 0.12 & 0.05 & -0.11 & -0.17 & & & & & & & & & \\
\hline 7. Host country GDP & 8.20 & 1.10 & -0.02 & 0.06 & 0.05 & -0.05 & 0.07 & 0.30 & & & & & & & & \\
\hline 8. Economic freedom & 57.47 & 5.72 & 0.05 & 0.07 & -0.12 & -0.27 & -0.12 & 0.48 & -0.05 & & & & & & & \\
\hline 9. Bureaucracy quality & 0.59 & 0.12 & 0.00 & 0.09 & -0.09 & -0.23 & -0.13 & 0.65 & 0.01 & 0.86 & & & & & & \\
\hline 10. Law and order & 0.61 & 0.09 & -0.04 & 0.21 & 0.04 & -0.26 & -0.17 & 0.57 & 0.07 & 0.62 & 0.73 & & & & & \\
\hline 11. Subsidiary size & 979.8 & 1207.6 & 0.19 & -0.05 & -0.04 & 0.30 & 0.07 & -0.05 & -0.07 & -0.09 & -0.06 & -0.04 & & & & \\
\hline 12. Ownership & 0.74 & 0.31 & -0.12 & -0.06 & 0.21 & 0.20 & -0.05 & 0.27 & 0.37 & 0.08 & 0.16 & 0.16 & 0.19 & & & \\
\hline 13. Industry & 0.85 & 0.36 & -0.07 & -0.11 & 0.08 & -0.17 & 0.13 & 0.05 & 0.21 & 0.10 & 0.14 & 0.09 & 0.03 & 0.22 & & \\
\hline 14. Intra-regional diversification & 0.49 & 0.44 & 0.15 & -0.01 & 0.07 & 0.51 & 0.62 & -0.31 & 0.03 & -0.23 & -0.20 & -0.24 & 0.10 & 0.20 & 0.07 & \\
\hline 15. Inter-regional diversification & 0.46 & 0.42 & 0.29 & -0.04 & -0.05 & -0.05 & 0.37 & 0.02 & 0.12 & 0.29 & 0.16 & 0.13 & 0.02 & -0.05 & 0.15 & 0.03 \\
\hline
\end{tabular}

Note: Pearson correlation (Two-tailed). Correlation coefficients (absolute value) greater than 0.19 are significant at 0.05 level; greater than 0.26 at 0.01 level. Other correlations are not significant. 
(3) Downstream sample: MNEs with only downstream subsidiaries $(\mathrm{N}=124)$

\begin{tabular}{|c|c|c|c|c|c|c|c|c|c|c|c|c|c|c|c|c|}
\hline Variable & Mean & s.d. & 1 & 2 & 3 & 4 & 5 & 6 & 7 & 8 & 9 & 10 & 11 & 12 & 13 & 14 \\
\hline 1. MNE size & 8.56 & 15.13 & & & & & & & & & & & & & & \\
\hline 2. MNE age & 44.34 & 16.84 & 0.10 & & & & & & & & & & & & & \\
\hline 3. MNE ROA & 4.41 & 5.35 & 0.06 & -0.28 & & & & & & & & & & & & \\
\hline 4. Depth of Internationalization & 0.33 & 0.26 & -0.16 & -0.13 & 0.02 & & & & & & & & & & & \\
\hline 5. International experience & 203.45 & 295.76 & 0.45 & 0.16 & -0.12 & 0.07 & & & & & & & & & & \\
\hline 6. Cultural distance & 2.20 & 0.61 & -0.01 & 0.20 & -0.12 & -0.14 & -0.07 & & & & & & & & & \\
\hline 7. Host country GDP & 8.31 & 0.68 & -0.04 & 0.07 & -0.02 & -0.08 & -0.05 & 0.62 & & & & & & & & \\
\hline 8. Economic freedom & 64.96 & 6.05 & 0.02 & 0.09 & -0.08 & -0.17 & 0.02 & 0.52 & -0.04 & & & & & & & \\
\hline 9. Bureaucracy quality & 0.72 & 0.12 & 0.05 & 0.10 & -0.10 & -0.16 & 0.03 & 0.70 & 0.26 & 0.86 & & & & & & \\
\hline 10. Law and order & 0.69 & 0.08 & 0.03 & 0.15 & -0.22 & -0.12 & 0.04 & 0.68 & 0.24 & 0.66 & 0.76 & & & & & \\
\hline 11. Subsidiary size & 81.59 & 191.04 & 0.04 & 0.10 & 0.04 & 0.20 & -0.05 & -0.17 & -0.27 & -0.37 & -0.40 & -0.22 & & & & \\
\hline 12. Ownership & 0.92 & 0.14 & -0.04 & -0.12 & 0.04 & 0.09 & 0.05 & 0.06 & -0.07 & 0.37 & 0.34 & 0.22 & -0.27 & & & \\
\hline 13. Industry & 0.52 & 0.50 & -0.01 & -0.06 & 0.12 & 0.20 & -0.14 & 0.06 & 0.10 & 0.20 & 0.29 & 0.19 & -0.20 & 0.34 & & \\
\hline 14. Intra-regional diversification & 0.96 & 0.56 & 0.29 & 0.05 & -0.07 & -0.05 & 0.62 & -0.29 & -0.25 & -0.06 & -0.13 & 0.01 & -0.06 & 0.05 & -0.22 & \\
\hline 15. Inter-regional diversification & 0.91 & 0.43 & 0.33 & 0.05 & -0.06 & -0.10 & 0.44 & -0.09 & -0.10 & 0.14 & 0.16 & 0.21 & -0.10 & 0.13 & 0.06 & 0.25 \\
\hline
\end{tabular}

Note: Pearson correlation (Two-tailed). Correlation coefficients (absolute value) greater than 0.15 are significant at 0.05 level; greater than 0.22 at 0.01 level. Other correlations are not significant. 
Table 3. The results of hierarchical regression analyses

\begin{tabular}{|c|c|c|c|c|c|c|c|c|c|c|c|c|}
\hline \multirow[b]{2}{*}{ Variable } & \multicolumn{4}{|c|}{ (1) Full sample $(\mathrm{N}=130)$} & \multicolumn{4}{|c|}{ (2) Manufacturing sample $(\mathrm{N}=80)$} & \multicolumn{4}{|c|}{ (3) Downstream sample $(\mathrm{N}=124)$} \\
\hline & Model 1 & Model 2 & Model 3 & Model 4 & Model 5 & Model 6 & Model 7 & Model 8 & Model 9 & Model 10 & Model 11 & Model 12 \\
\hline Constant & $\begin{array}{c}15.63 \\
(26.80)\end{array}$ & $\begin{array}{c}15.65 \\
(26.91)\end{array}$ & $\begin{array}{c}26.27 \\
(25.05)\end{array}$ & $\begin{array}{c}32.60 \\
(24.03)\end{array}$ & $\begin{array}{c}14.40 \\
(13.04)\end{array}$ & $\begin{array}{c}14.43 \\
(13.13)\end{array}$ & $\begin{array}{c}12.64 \\
(13.92)\end{array}$ & $\begin{array}{c}12.10 \\
(14.04)\end{array}$ & $\begin{array}{c}44.83 \\
(37.14)\end{array}$ & $\begin{array}{c}55.53 \\
(34.77)\end{array}$ & $\begin{array}{c}49.05 \\
(35.67)\end{array}$ & $\begin{array}{l}57.52 \dagger \\
(33.88)\end{array}$ \\
\hline MNE size & $0.17^{*}$ & $0.17 *$ & $0.12 \dagger$ & $0.14 *$ & $\begin{array}{l}0.04 \\
(0.06)\end{array}$ & $\begin{array}{c}0.04 \\
(006)\end{array}$ & $\begin{array}{l}0.04 \\
(0.06)\end{array}$ & $\begin{array}{c}0.04 \\
(0.06)\end{array}$ & $0.17^{*}$ & $0.18^{*}$ & $0.14 \dagger$ & $0.15 \dagger$ \\
\hline MNE age & $\begin{array}{c}0.00 \\
(0.06)\end{array}$ & $\begin{array}{c}0.00 \\
(0.06)\end{array}$ & $\begin{array}{c}0.02 \\
(0.05)\end{array}$ & $\begin{array}{c}0.03 \\
0.05)\end{array}$ & $-0.11 *$ & $-0.11 \dagger$ & $-0.12 *$ & $-0.11 \dagger$ & -0.01 & 0.00 & 0.00 & 0.00 \\
\hline MNE ROA & $\begin{array}{c}(0.06) \\
-0.52 * * \\
(0.18)\end{array}$ & $\begin{array}{c}(0.06) \\
-0.52 * * \\
(0.19)\end{array}$ & $\begin{array}{c}(0.05) \\
-0.53 * * \\
(0.17)\end{array}$ & $\begin{array}{c}(0.05) \\
-0.50 * * \\
(0.16)\end{array}$ & $\begin{array}{c}(0.05) \\
-0.09 \\
(0.16)\end{array}$ & $\begin{array}{l}(0.06) \\
-0.08 \\
(0.16)\end{array}$ & $\begin{array}{c}(0.06) \\
-0.10 \\
(016)\end{array}$ & $\begin{array}{l}(0.06) \\
-0.09 \\
(0.16)\end{array}$ & $\begin{array}{l}(0.07) \\
-0.49^{*} \\
(0.22)\end{array}$ & $\begin{array}{l}(0.07) \\
-0.45^{*} \\
(021)\end{array}$ & $\begin{array}{l}(0.07) \\
-0.50^{*} \\
(021)\end{array}$ & $\begin{array}{c}(0.07) \\
-0.47^{*} \\
(02)\end{array}$ \\
\hline Depth of Internationalization & $\begin{array}{c}-16.97 * * * \\
(4.45)\end{array}$ & $\begin{array}{c}-17.09 * * * \\
(4.5)\end{array}$ & $\begin{array}{c}-17.33 * * * \\
(4.15)\end{array}$ & $\begin{array}{c}-15.44 * * * \\
(4.00)\end{array}$ & $\begin{array}{l}-4.66 \\
(3.75)\end{array}$ & $\begin{array}{l}-3.82 \\
(4.29)\end{array}$ & $\begin{array}{l}-4.64 \\
(3.77)\end{array}$ & $\begin{array}{l}(0.10) \\
-3.56 \\
(4.35)\end{array}$ & $\begin{array}{c}-9.59^{*} \\
(4.78)\end{array}$ & $\begin{array}{l}-11.43 \\
(4.48)\end{array}$ & $\begin{array}{c}-7.78 \dagger \\
(4.62)\end{array}$ & $\begin{array}{c}-9.78 * \\
(4.41)\end{array}$ \\
\hline International experience & $\begin{array}{l}-0.01^{*} \\
(0.00)\end{array}$ & $\begin{array}{c}-0.01 * \\
(0.00)\end{array}$ & $\begin{array}{c}-0.01 * * * \\
(0.00)\end{array}$ & $\begin{array}{c}0.00 \\
(0.00)\end{array}$ & $\begin{array}{l}-0.02 \\
(0.02)\end{array}$ & $\begin{array}{c}0.00 \\
(0.02)\end{array}$ & $\begin{array}{c}-0.02 \\
(0.02)\end{array}$ & $\begin{array}{l}-0.01 \\
(0.02)\end{array}$ & $\begin{array}{l}-0.01^{*} \\
(0.00)\end{array}$ & $\begin{array}{c}0.00 \\
(0.01)\end{array}$ & $\begin{array}{c}-0.02 * * * \\
(0.00)\end{array}$ & $\begin{array}{l}-0.01 \\
(0.01)\end{array}$ \\
\hline Cultural distance & $\begin{array}{l}-4.08 \\
(3.15)\end{array}$ & $\begin{array}{l}-3.82 \\
(3.36)\end{array}$ & $\begin{array}{l}-2.32 \\
(2.96)\end{array}$ & $\begin{array}{l}-5.71 \dagger \\
(3.00)\end{array}$ & $\begin{array}{l}-0.36 \\
(1.47)\end{array}$ & $\begin{array}{l}-0.63 \\
(1.61)\end{array}$ & $\begin{array}{c}-0.39 \\
(1.48)\end{array}$ & $\begin{array}{l}-0.75 \\
(1.64)\end{array}$ & $\begin{array}{c}1.81 \\
(4.21)\end{array}$ & $\begin{array}{l}-2.00 \\
(4.04)\end{array}$ & $\begin{array}{c}5.35 \\
(4.18)\end{array}$ & $\begin{array}{l}1.25 \\
(4.12)\end{array}$ \\
\hline Host country GDP & $\begin{array}{l}-0.62 \\
(2.13)\end{array}$ & $\begin{array}{l}-0.60 \\
(2.14)\end{array}$ & $\begin{array}{l}-1.14 \\
(1.98)\end{array}$ & $\begin{array}{l}-1.80 \\
(1.91)\end{array}$ & $\begin{array}{c}0.62 \\
(0.79)\end{array}$ & $\begin{array}{c}0.63 \\
(0.79)\end{array}$ & $\begin{array}{c}0.67 \\
(0.81)\end{array}$ & $\begin{array}{c}0.70 \\
(0.81)\end{array}$ & $\begin{array}{l}-3.16 \\
(2.94)\end{array}$ & $\begin{array}{l}-3.78 \\
(2.75)\end{array}$ & $\begin{array}{l}-3.65 \\
(2.82)\end{array}$ & $\begin{array}{l}-4.09 \\
(2.68)\end{array}$ \\
\hline Economic freedom & $\begin{array}{c}0.66 \\
(0.28)\end{array}$ & $\begin{array}{l}0.65^{*} \\
(0.28)\end{array}$ & $\begin{array}{l}0.48 \dagger \\
(0.26)\end{array}$ & $\begin{array}{l}0.57^{*} \\
(0.25)\end{array}$ & $\begin{array}{c}0.09 \\
(0.26)\end{array}$ & $\begin{array}{c}0.07 \\
(0.26)\end{array}$ & $\begin{array}{c}0.12 \\
(0.28)\end{array}$ & $\begin{array}{c}0.12 \\
(0.28)\end{array}$ & $\begin{array}{c}-0.28 \\
(0.45)\end{array}$ & $\begin{array}{c}-0.35 \\
(0.42)\end{array}$ & $\begin{array}{c}-0.2 \\
(0.43)\end{array}$ & $\begin{array}{c}-0.28 \\
(0.41)\end{array}$ \\
\hline Bureaucracy quality & $\begin{array}{l}-4.55 \\
(5.61)\end{array}$ & $\begin{array}{l}-4.81 \\
(5.74)\end{array}$ & $\begin{array}{c}-4.17 \\
(5.22)\end{array}$ & $\begin{array}{c}0.41 \\
(5.17)\end{array}$ & $\begin{array}{c}-9.27 \\
(14.9)\end{array}$ & $\begin{array}{c}-7.91 \\
(15.36)\end{array}$ & $\begin{array}{c}-10.24 \\
(15.22)\end{array}$ & $\begin{array}{c}-8.81 \\
(15.56)\end{array}$ & $\begin{array}{c}18.29 \\
(26.53)\end{array}$ & $\begin{array}{c}11.14 \\
(24.83)\end{array}$ & $\begin{array}{c}8.05 \\
(25.66)\end{array}$ & $\begin{array}{c}3.99 \\
(24.34)\end{array}$ \\
\hline Law and order & $\begin{array}{l}-8.67 \\
(6.73)\end{array}$ & $\begin{array}{l}-9.03 \\
(6.93)\end{array}$ & $\begin{array}{c}-14.78^{*} \\
(6.42)\end{array}$ & $\begin{array}{c}-12.51 * \\
(6.17)\end{array}$ & $\begin{array}{c}2.28 \\
(13.05)\end{array}$ & $\begin{array}{c}1.99 \\
(13.15)\end{array}$ & $\begin{array}{c}2.90 \\
(13.24)\end{array}$ & $\begin{array}{c}2.73 \\
(13.32)\end{array}$ & $\begin{array}{c}14.38 \\
(22.01)\end{array}$ & $\begin{array}{l}43.38^{*} \\
(21.71)\end{array}$ & $\begin{array}{c}-3.30 \\
(21.82)\end{array}$ & $\begin{array}{c}25.92 \\
(22.17)\end{array}$ \\
\hline Subsidiary size & $\begin{array}{c}0.00 \\
(0.00)\end{array}$ & $\begin{array}{c}0.00 \\
(0.00)\end{array}$ & $\begin{array}{c}0.00 \\
(0.00)\end{array}$ & $\begin{array}{c}0.00 \\
(0.00)\end{array}$ & $\begin{array}{c}0.00 \\
(0.00)\end{array}$ & $\begin{array}{c}0.00 \\
(0.00)\end{array}$ & $\begin{array}{c}0.00 \\
(0.00)\end{array}$ & $\begin{array}{c}0.00 \\
(0.00)\end{array}$ & $\begin{array}{c}-0.01 \dagger \\
(0.01)\end{array}$ & $\begin{array}{l}-0.02 * \\
(0.01)\end{array}$ & $\begin{array}{c}-0.01^{*} \\
(0.01)\end{array}$ & $\begin{array}{l}-0.02 * \\
(0.01)\end{array}$ \\
\hline Ownership & $\begin{array}{l}-0.32 \\
(6.12)\end{array}$ & $\begin{array}{c}-0.68 \\
(6.33)\end{array}$ & $\begin{array}{l}-2.82 \\
(5.72)\end{array}$ & $\begin{array}{c}1.72 \\
(5.63)\end{array}$ & $\begin{array}{l}-2.94 \\
(2.82)\end{array}$ & $\begin{array}{l}-2.60 \\
(2.95)\end{array}$ & $\begin{array}{l}-3.05 \\
(2.85)\end{array}$ & $\begin{array}{l}-2.66 \\
(2.97)\end{array}$ & $\begin{array}{c}4.50 \\
(9.14)\end{array}$ & $\begin{array}{c}7.16 \\
(8.56)\end{array}$ & $\begin{array}{c}3.32 \\
(8.78)\end{array}$ & $\begin{array}{c}5.01) \\
5.90 \\
(8.35)\end{array}$ \\
\hline Industry & $\begin{array}{l}-1.55 \\
(1.87)\end{array}$ & $\begin{array}{c}-1.57 \\
(1.88)\end{array}$ & $\begin{array}{l}-2.60 \\
(1.76)\end{array}$ & $\begin{array}{l}-2.92 \dagger \\
(1.68)\end{array}$ & $\begin{array}{l}-4.8^{*} \\
(2.36)\end{array}$ & $\begin{array}{l}-4.75^{*} \\
(2.38)\end{array}$ & $\begin{array}{l}-4.73 \dagger \\
(2.38)\end{array}$ & $\begin{array}{c}-4.65 \dagger \\
(2.4)\end{array}$ & $\begin{array}{l}1.76 \\
(2.67)\end{array}$ & $\begin{array}{c}-0.27 \\
(2.54)\end{array}$ & $\begin{array}{l}1.68 \\
(2.56)\end{array}$ & $\begin{array}{l}-0.08 \\
(2.48)\end{array}$ \\
\hline Intra-regional diversification & & $\begin{array}{l}1.06 \\
(4.56)\end{array}$ & & $\begin{array}{c}-17.93 * * \cdots \\
(5.24)\end{array}$ & & $\begin{array}{l}-1.19 \\
(2.88)\end{array}$ & & $\begin{array}{l}-1.52 \\
(2.98)\end{array}$ & & $\begin{array}{c}-11.20^{* * *} \\
(2.70)\end{array}$ & & $\begin{array}{c}-9.82^{*} * * \\
(2.69)\end{array}$ \\
\hline Inter-regional diversification & & & $\begin{array}{c}10.15^{* * *} * \\
(2.33)\end{array}$ & $\begin{array}{c}16.45^{* * *} * \\
(2.89)\end{array}$ & & & $\begin{array}{l}-0.81 \\
(2.12)\end{array}$ & $\begin{array}{l}-1.07 \\
(2.19)\end{array}$ & & & $\begin{array}{c}9.64 * * \\
(2.99)\end{array}$ & $\begin{array}{l}7.57 * * \\
(2.89)\end{array}$ \\
\hline$R^{2}$ & 0.44 & 0.44 & 0.52 & 0.57 & 0.25 & 0.25 & 0.25 & 0.26 & 0.26 & 0.36 & 0.33 & 0.40 \\
\hline Adjusted $R^{2}$ & 0.38 & 0.37 & 0.46 & 0.51 & 0.10 & 0.09 & 0.09 & 0.08 & 0.17 & 0.28 & 0.24 & 0.32 \\
\hline$\Delta R^{2}$ & & 0.00 & 0.08 & 0.13 & & 0.00 & 0.00 & 0.01 & & 0.10 & 0.06 & 0.14 \\
\hline Model F & 7.06 & 6.51 & 8.93 & 9.89 & 1.69 & 1.56 & 1.56 & 1.46 & 2.99 & 4.41 & 3.76 & 4.80 \\
\hline$\Delta F$ & & 0.06 & $18.96^{* * *}$ & $11.70 * * *$ & & 0.17 & 0.15 & 0.26 & & $17.15 * * *$ & $10.42 * *$ & $13.34 * * *$ \\
\hline
\end{tabular}

Note: Standard errors in parentheses, $\dagger \mathrm{p}<0.1,{ }^{*} \mathrm{p}<0.05,{ }^{*} \mathrm{p}<0.01,{ }^{* * *} \mathrm{p}<0.001$. 